\title{
Demographic Change and the Future of Congress
}

\author{
Kathryn Pearson, University of Minnesota
}

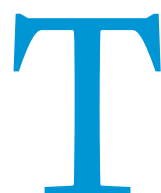

he United States population is changing in significant ways: it is growing larger, older, and more racially and ethnically diverse, and these changes are regionally concentrated. How will these changes affect the future of Congress? In this article, I show that demographic change has significant implications for the quality of representation, the legislative agenda, party coalitions, and the diversity of congressional membership in the future, even as change inside Congress will proceed more slowly than change outside it.

Population growth in the United States presents a representational dilemma for future Congresses. Designed to elect members "closest to the people," House districts have grown more populous-and further afield from the framers' vision of districts of 30,000 constituents-for nearly 100 years. In the next decade, the average district population will rise to 710,000 , a $10 \%$ increase from the past 10 years and a $24 \%$ increase from the 1990s (Giroux 2009). According to the U.S. Census, the United States is projected to reach the 400 million population milestone in 2039, translating into districts of, on average, 920,000 people (http://www.census.gov/population/www/ projections/2008projections.html).

As members of Congress represent more and more people, the quality of constituent representation is likely to suffer, particularly when it comes to members' interactions with their constituents. Increasingly populated districts will translate into increased demands on members' time, with more requests for casework, assistance with grants, school visits, public appearances, constituent meetings, and mail. Members and their staff will struggle to fulfill constituents' requests and to interact with significant shares of their constituents in their districts, fueling claims that members of Congress are "out of touch." Reports of overcrowded town hall meetings turning away angry constituents could increase. Technological advances will mitigate some of the representational losses associated with growing constituencies as members are more easily able to convey information, but e-mail and social networking should be a complement to, not substitute for, members' personal "homestyle" (Fenno 1978) in their districts.

There is no costless remedy for the problems associated with increasingly populous districts. But as the 400 million population milestone approaches, it is worth evaluating the tradeoffs associated with increasing the membership of the House of Representatives. Creating more House districts would enhance citizens' opportunities to interact with their representatives and their staffs and facilitate members' responsiveness to local concerns. Additional seats would also create opportunities for potential candidates who have much to con- tribute and who would otherwise spend years waiting for incumbents to retire. These representational gains, however, would likely accrue at the cost of inefficiency in congressional operations and policymaking. A larger membership could make coalition building and entrepreneurship inside Congress more difficult, exacerbating partisan centralization and the incivility that stems in part from a lack of personal ties and interaction among members.

The aging of the population will have significant consequences for the future of Congress. In 2000, the percent of the population aged 65 and older was $12.4 \%$. By 206o, it will be $20 \%$. This will shape the policy agenda, as members are forced to consider entitlements and a host of other issues affecting the aged-a growing and active share of their constituency (see, e.g., Wilmoth and Longino 2006).

U.S. Census data reveal that U.S. population growth is concentrated in the Sun Belt; future Congresses will see an increase in the ranks of members from the South and West and a decrease in members from Rust Belt states. The geographic redistribution of House seats in future Congresses has significant implications for representation, policy, and the Electoral College vote.

In every reapportionment since World War II, southern and western states have gained congressional seats at the expense of midwestern and northwestern states. Indeed, since the 1950s, Arizona's delegation has quadrupled; Florida's has tripled; and California's has grown 77\% (Giroux 2009, 2768). In November 2009, Election Data Services Inc. predicted that eight states-all in the Sun Belt-will gain seats, and eleven states-primarily in the Midwest and Northeast-will lose seats after the 2010 Census (Giroux 2009, 2768).

These trends will continue in the next several rounds of redistricting. According to analysis done by David Wasserman of the Crystal Ball (http://www.centerforpolitics.org/crystalball/), the states with the biggest projected seat gains between 2010 and 2030 are: Florida (9), Texas (8), Arizona (5), California (3), Nevada (2), and North Carolina (2). The biggest projected losers, in order, are New York, Ohio, Pennsylvania, Illinois, Massachusetts, and Michigan. Overall, Wasserman projects that the South will gain 17 seats and the West will gain 13 seats, while the Northeast will lose 15 seats and the Midwest will lose 14 seats (Wasserman 2007).

Current population growth is closely connected to growth in minority populations in geographically concentrated regions; the biggest population growth is occurring in states with the largest numbers of people of color. Of course, growing states will gain House seats, including some majority-minority districts. Regionally concentrated growth, however, also means 
that the representational disparities caused by Senate malapportionment will increase in the states with the biggest shares of Hispanics-who are already underrepresented descriptively in Congress-such as California, Texas, and Florida.

When it comes to representation in Congress, demographic change has both demand-side effects (voters) and supply-side effects (candidates). Increased racial and ethnic diversity in the population at large, coupled with other societal changes, promises to continue to diversify the composition of Congress itself, even if gradually. Racial differences in candidate emergence and patterns of political socialization, the naturalization and assimilation process, and other institutional and political barriers for people of color, combined with the stickiness of incumbency in general, suggest that change inside Congress will proceed more slowly than changes outside of Congress.

Congress is not descriptively representative (see, e.g., Pitkin 1967) of the U.S. population. Women and people of color have historically been, and continue to be, underrepresented in the House and Senate. This underrepresentation has potentially negative implications for the legitimacy of Congress as a representative body, the participation and willingness of voters to contact and trust their representatives, and the substantive representation of people of color and women across the country (see, e.g., Mansbridge 1999). Indeed, research reveals that Latinos represented by Latinos are less likely to report political alienation (Pantoja and Segura 2003); descriptive representation increases the probability that black constituents will contact their representatives (Gay 2002); and women are more likely to support gender-based descriptive representation than men (Sanbonmatsu 2003).

Unless more women candidates and non-white candidates run and win, the gap between Congress and the U.S. population will continue to increase as the demographics of the U.S. change. According to the U.S. Census, racial and ethnic minorities, now roughly one-third of the U.S. population, are expected to become the majority in 2042 , with the nation projected to be $54 \%$ minority in 2050. People of color-everyone except for non-Hispanic, single-race whites-will comprise 235.7 million out of a total U.S. population of 439 million in 2050. Non-Hispanic whites are projected to lose population in the 2030 and 2040 and comprise $46 \%$ of the total population in 2050, down from $66 \%$ in 2008 . By 2023, minorities will comprise more than half of all children.

There has been significant growth in the ranks of the Congressional Black Caucus in the past 20 years, but the prospects for continued growth in the power and numbers of African Americans in Congress are contingent upon the success of African American candidates in districts where African Americans do not comprise a majority. In 2009, one African American served in the Senate and 39 African Americans served in the House; additionally, there were two delegates. By contrast, in 1989, only 24 African Americans served in Congress, all of whom served in the House. In the 1992 elections, newly drawn majorityminority districts created new opportunities for African American legislators, and the number of African Americans serving in Congress increased from 25 to 38 , but there has been little growth since then. Redistricting is unlikely to produce such big gains again; after new majority-minority districts that were created following the 1990 Census, the Supreme Court ruled that race cannot be the predominant factor in reapportionment.

Most minority legislators represent majority-minority districts (Lublin et al. 2009). Yet, the prospect for growth in African American members from majority-minority districts is limited; indeed the number of majority-black congressional districts decreased from 1992 to 2007 (Lublin et al. 2009). Relative to other groups, African Americans are not a fast-growing group. According to the U.S. Census, the black population is projected to increase from 41.1 million in $2008,14 \%$ of the population, to 65.7 million in $2050,15 \%$ of the population.

With significant gains from additional majority-minority districts ruled out, this means that the best prospect for growth in the ranks of African Americans in Congress is for white voters to join with minority voters in support of African American candidates-new-style candidates, as David Canon describes them, who pursue the politics of commonality (Canon 1999). While minority candidates have occasionally won in majoritywhite districts, non-white candidates are much more likely to win when a majority is composed of a black-Hispanic coalition (Lublin et al. 2009). Some political analysts have been skeptical, as the ranks of African Americans representing majority-white districts is small. And in the Senate, where no state is comprised of a majority of African Americans, there is only one African American. But the prospects for electing African Americans from majority-white districts seems much more promising since the election of president Barack Obama, who essentially campaigned on the politics of commonality on the national scale. Although it is difficult to predict the long-term effect of Obama's presidency on African American-candidate emergence in majority-white districts and on congressional voting behavior, it suggests promise.

Hispanics are the fastest-growing demographic group; the Hispanic population is projected to nearly triple, from 46.7 million to 132.8 million, during the 2008-2050 period, according to the U.S. Census. Its share of the nation's total population is projected to double, from $15 \%$ to $30 \%$ by 2050 . Only 12 Hispanic members served in the House in 1989 , increasing to 17 members after the 1992 elections, and the Hispanic Caucus in the House has continued to increase ever since. After the 2008 elections, 24 Hispanics served in the House (and one delegate) and three served in the Senate.

There is significant potential for growth in Hispanic representation in future Congresses, but increases in political participation among Hispanics, continued naturalization and assimilation among Hispanic immigrants, and increased candidate emergence are necessary preconditions. But even as the increase of Hispanics in Congress lags behind population growth, it is clear that the Hispanic Caucus will continue to grow, especially because the growth among Hispanics is regionally concentrated.

The incumbency advantage slows the translation of increased racial and ethnic diversity in the United States to the diversification of Congress. Indeed, the incumbency advantage is often among the factors blamed for the underrepresentation of people of color and women. Studies of term-limited state legislatures provide some insight into the 
effects of demographic change among elected officials when the incumbency factor is removed, revealing that minority representation has increased in isolated cases and that women have not been helped by term limits anywhere (see Kousser 2008). Research shows that in the California legislature there has been a notable increase in Hispanic legislators since term limits went into effect, but a slight decline among African American legislators (Cain and Kousser 2004).

U.S. Census data show that the Asian American population is projected to climb from 15.5 million to 40.6 million by 2050, with its share of the nation's population expected to rise from $5.1 \%$ to $9.2 \%$. Even when accounting for institutional factors like the stickiness of incumbency and political factors like political participation rates and the lack of majority-Asian districts, with six Asian Americans in the House (plus two delegates) and two in the Senate in 2009, it seems likely that growth in the ranks of Asian American members will follow the population growth.

Predicting changes in women's representation reflects a different set of calculations based on changes in the candidate pool rather than the share of women in the electorate. Women comprise $51 \%$ of the population (and slightly more of the electorate) and are generally not concentrated in geographic areas. Twenty years ago, only 25 women served in the House, and two served in the Senate. 1992 was a watershed year for women, with the number of women in the House nearly doublingfrom 29 to 47 . Indeed, after so many politically experienced women ran and won in 1992, particularly in open seats, political scientists predicted that the "pipeline" of women in lower office would provide consistent increases in the number of women serving in the House. Yet, women's gains in the House since then have been steady but small. In 2009, 73 women served in the House and 17 in the Senate.

What are the prospects for great increases in women's representation in future Congresses? Nancy Pelosi shattered the glass ceiling of congressional leadership when she became Speaker in 2007, but gender parity in Congress is unlikely in the near future. It isn't that women don't win-extensive research reveals that controlling for relevant factors, women win at the same rate as men in general and primary House elections (see, e.g., Seltzer, Newman, and Leighton 1997; Smith and Fox 2001; Lawless and Pearson 2008). Instead, the increase in women candidates has stalled, and, among non-incumbents, has even been declining. And given that the number of women in state legislatures-the best pipeline to the U.S. Congresshas also plateaued (Sanbonmatsu 2006), there is not likely to be a sharp rise women's candidacies anytime soon. Research by Jennifer Lawless and Richard Fox (2005) underscores this gender gap in candidate emergence. In a national survey of nearly 4,ooo professionals, when women and men who occupy the same professions are compared, women are significantly less likely to likely to express interest in running, in part because women see themselves as less qualified to run for office than men with the same qualifications.

Taken together, the slow but steady growth in the number of women, African Americans, and Asian Americans in Congress, along with potentially more rapid growth in the number of Hispanic members, will affect the Democratic Caucus to a much greater extent than it will the Republican Conference. These significant House Democratic Caucus subgroups, including the Congressional Hispanic Caucus, the Congressional Black Caucus, and women, will become larger and stronger (although representing a somewhat broader representational base) with concomitant demands for representation on committees, in leadership, and on the policy agenda.

Among Hispanics in the 111th Congress, Democrats outnumber Republicans by 23 to 4 . Partisan identification among Hispanics and Asians in the electorate is less lopsided, although Obama received $67 \%$ of the Hispanic vote in 2008 and $62 \%$ of the Asian vote. Six of eight Asian Americans in Congress are Democrats, and all African Americans are Democrats. With a growing coalition of non-white members in the Democratic Caucus, the Black Caucus and the Hispanic Caucus will be better positioned to make demands on Democratic Party leaders, particularly by working together. Already, the Black Caucus, Hispanic Caucus, and Asian Pacific American Caucus have formed the Congressional Tri-Caucus to put their common issues on the agenda. And while the seniority system once meant that conservative Democratic committee chairs from the South were overrepresented as committee chairs (see, e.g., Rohde 1991), the seniority system in 2009 helped long-serving African Americans maintain key committee chairmanships, such as Judiciary Committee chairman John Conyers (D-MI) and Ways and Means chairman Charlie Rangel (D-NY), who represent safe, urban districts.

Despite the prominence of a small but vocal cadre of conservative women in the 111th House, the partisan gender gap in Congress is as large as it has ever been- $77 \%$ of congresswomen are Democrats. Research by Palmer and Simon (2006) shows that certain types of districts send women to Congress: specifically, urban, Democratic, diverse, and well-educated districts. The partisan gender gap in Congress is thus likely to persist in future Congresses as the number of women slowly increases, meaning that women will comprise a larger share of the Democratic Caucus and its party and committee leadership.

It is unlikely that future Congresses will see congresswomen working together across party lines to the same extent as they have in the past. Research conducted on congresswomen's legislative activities before Republicans achieved majority-party control of Congress in the 1994 elections found that Democratic and Republican congresswomen alike were more likely than their male counterparts to vote for and sponsor issues of importance to women such as child care, women's health, access to abortion, domestic violence prevention, and pay equity (see, e.g., Dodson 2006; Swers 1998, 2002). Indeed, research also suggests that congresswomen are better at building consensus than congressmen (see, e.g., Gelb and Palley 1996; Kathlene 1994). The high levels of partisan polarization and partisan acrimony detailed by Matthew Green in this symposium, coupled with the disappearance of moderate Republican congresswomen, however, have translated into partisan divides among congresswomen that are as strong-if not stronger-than those between congressmen. In the 110th Congress, congresswomen were as or more loyal to their party in their voting records than congressmen, and Republican congresswomen gave significantly 
more partisan one-minute speeches attacking Democrats than Republican congressmen did (Pearson 2009). Bipartisan cooperation among congresswomen in the House is likely to continue to deteriorate as partisan identity and partisan incentives prevail in a polarized environment. In the Senate, by contrast, electoral and institutional differences, particularly the rise of the "6o vote Senate" detailed by Frances Lee, gives ideologically moderate women in the Senate incentives to work across party lines to forge compromise, a trend that is likely to continue.

White male Democratic members are, on average, less liberal than their female and African American and Hispanic counterparts. The Progressive Caucus draws disproportionately from these members and will likely grow as well, giving the Blue Dog Coalition incentives to differentiate itself from liberal Democrats. Decreases in the ranks of white males within the Democratic Caucus will have consequences for party leaders balancing competing demands of its members' policy goals and electoral imperatives. The diversity of the Republican Conference in future Congresses is uncertain. Republicans face the serious challenge of attracting minority voters in the future, whether with the party's typically white candidates or with non-white Republicans.

Beyond changing the dynamics within each party caucus, increased diversity inside Congress and also within white members' districts will affect the legislative agenda, giving increased voice and weight to the concerns of non-white voters. Population growth, geographic shifts, the aging of the population, and increased racial and ethnic diversity will have profound effects on the future of Congress in ways that scholars, and Congress itself, have barely begun to address or even contemplate.

\section{REFERENCES}

Cain, Bruce E., and Thad Kousser. 2004. Adapting to Term Limits: Recent Experiences and New Directions. San Francisco: Public Policy Institute of California.

Canon, David. 1999. Race, Redistricting, and Representation: The Unintended Consequences of Black Majority Districts. Chicago: University of Chicago Press.

Dodson, Debra L. 2006. The Impact of Women in Congress. New York: Oxford University Press.

Fenno, Richard. 1978. Homestyle. Boston: Little, Brown and Company.

Gay, Claudine. 2002. "Spirals of Trust: The Effect of Descriptive Representation on the Relationship Between Citizens and their Government." American Journal of Political Science 46: 717-32.
Gelb, Joyce, and Marian Lief Palley. 1996. Women and Public Policies: Reassessing Gender Politics. Charlottesville: University of Virginia Press.

Giroux, Greg. 2009. "Before Redistricting, That Other 'R' Word." CQ Weekly, November 30, 2768-69.

Kathlene, Lyn. 1994. "Power and Influence in State Legislative Policymaking: The Interaction of Gender and Position in Committee Hearing Debates." American Political Science Review 88 (3): 560-76.

Kousser, Thad. 2008. "Term Limits and State Legislatures." In Democracy in the States: Experiments in Election Reform, ed. Caroline Tolbert, Todd Donovan, and Bruce E. Cain. Washington, D.C.: Brookings Institution Press.

Lawless, Jennifer L., and Richard Fox. 2005. It Takes a Candidate: Why Women Don't Run for Office. New York: Cambridge University Press.

Lawless, Jennifer L., and Kathryn Pearson. 2008. "The Primary Reason for Women's Under-Representation? Re-Evaluating the Conventional Wisdom." The Journal of Politics 70 (1): 67-82.

Lublin, David, Thomas L. Brunell, Bernard Grofman, and Lisa Handley. 2009 "Has the Voting Rights Act Outlived Its Usefulness: In a Word, 'No."” Legislative Studies Quarterly 34 (4): 525-54.

Mansbridge, Jane J. 1999. "Should Blacks Represent Blacks and Women Represent Women? A Contingent 'Yes.'” Journal of Politics 61 (3): 628-57.

Palmer, Barbara, and Dennis Simon. 2006. Breaking the Political Glass Ceiling: Women and Congressional Elections. New York: Routledge.

Pantoja, Adrian D., and Gary M. Segura. 2003. "Does Ethnicity Matter? Descriptive Representation in Legislatures and Political Alienation Among Latinos." Social Science Quarterly 84: 441-59.

Pearson, Kathryn. 2009. "Gendered Partisanship in the U.S. House and Senate." Paper prepared for delivery at the Conference on Legislative Elections, Process, and Policy: The Influence of Bicameralism, Vanderbilt University, October 22-24.

Pitkin, Hanna Fenichel. 1967. The Concept of Representation. Berkeley: University of California Press.

Rohde, David W. 1991. Parties and Leaders in the Postreform House. Chicago: University of Chicago Press.

Sanbonmatsu, Kira. 2003. Gender-Related Knowledge and the Descriptive Representation of Women. Political Behavior 25 (4): 367-87.

. 2006. Where Women Run: Gender and Party in the American States. Ann Arbor: University of Michigan Press.

Seltzer, Richard A., Jody Newman, and Melissa Voorhees Leighton. 1997. Sex as a Political Variable: Women as Candidates and Voters in U.S. Elections. Boulder: Lynne Rienner.

Smith, Eric R.A.N., and Richard L. Fox. 2001. "A Research Note: The Electoral Fortunes of Women Candidates for Congress." Political Research Quarterly 54 (1): 205-21.

Swers, Michele L. 1998. “Are Women More Likely to Vote for Women's Issues Bills than Their Male Colleagues?" Legislative Studies Quarterly 23 (3): 435-48.

. 2002. The Difference Women Make: The Policy Impact of Women in Congress. Chicago: The University of Chicago Press.

Wasserman, David. 2007. "When the Levee Breaks: Looking at the Big Picture in the House." Larry J. Sabato's Crystal Ball, March 15. http://www. centerforpolitics.org/crystalball/articles/dnw2007031501/.

Wilmoth, Janet, and Charles Longino. 2006. "Demographic Trends that Will Shape U.S. Policy in the Twenty-First Century." Research on Aging 28 (May): 269-88. 